\title{
Effect of Inflation, BI Rate And Net Export To USD Central Exchange Rate to Rupiahs In Bank Indonesia For 2005-2019
}

\author{
Sri Harjunawati ${ }^{1}$, Ida Hendarsih ${ }^{2}$, Syahrial Addin ${ }^{3}$, Amas Sari Marthanti ${ }^{4}$ \\ ${ }^{1,3}$ Faculty of Engineering and Informatics, Universitas Bina Sarana Informatika \\ ${ }^{2,4}$ Faculty of Economics and Business, Universitas Bina Sarana Informatika \\ 1sri.shw@bsi.ac.id, ${ }^{2}$ ida.idh@bsi.ac.id, ${ }^{3}$ syahrial.sra@bsi.ac.id, ${ }^{4}$ amas.mtm@bsi.ac.id
}

\begin{tabular}{ccc}
\hline Diterima & Direvisi & Disetujui \\
$12-03-2021$ & $14-03-2021$ & $25-03-2021$ \\
\hline
\end{tabular}

\begin{abstract}
Abstrak - This study discusses the USD Central Exchange Rate of USD To Rupiah at Bank Indonesia as a Dependency Factor $(\mathrm{Y})$, with independent factors that can approve internal aggregates, namely In ation (X1), BI Rate (X2), and Net Exports (X3). The hypothesis used in this study is In ation (X1) that applies to the USD Middle Rate Against Rupiah at Bank Indonesia (Y), whether the BI Rate (X2) is related to the USD Middle Rate Against Rupiah at Bank Indonesia (Y), whether Net Exports (Y X3) against the USD Exchange Rate Against Rupiah at Bank Indonesia (Y), and whether In ation (X1), BI Rate (X2), and Net Exports (X3) simultaneously oppose the USD Exchange Rate Against Rupiah at Bank Indonesia (Y). The data used are secondary data released by the Indonesian Central Statistics Agency and processed using SPSS.22. The classic test is done using the Normality Test, Autocorrelation Test, and Multicollinearity Test. Hypothesis testing is done using a Simple Linear Test and Multiple Linear Test. This research resulted in a calculated value of $\mathrm{X} 1$ against $\mathrm{Y}$ of -1.318 ; the value of $\mathrm{t}$-count $\mathrm{X} 2$ against $\mathrm{Y}$ is $-1,963$; and the $\mathrm{t}$-value of $\mathrm{X} 3$ against $\mathrm{Y}$ is $-3,803$. The $\mathrm{t}$-table value is negative in this study 2.16037. Multiple linear tests in this study produced a calculated $\mathrm{F}$ value of $4.670>3.587$ (F table). The regression equation in this study is $\mathrm{Y}=12,226,241-166,022 . \mathrm{X} 1+196,115 . \mathrm{X} 2-0,101 \cdot \mathrm{X} 3+\mathrm{e}$. The coe cient of $\mathrm{R}$ value is 0.748 and the value of $\mathrm{R}$ square is 0.56 .
\end{abstract}

Keywords: inflation, BI Rate, Net Export

\section{INTRODUCTION}

International trade has penetrated almost all countries, becoming one of the main factors to increase GDP (Gross Domestic Product), (Bps.go.id, 2021) GDP is basically the amount of added value produced by all business units in a particular country, or is the sum of the value of the final goods and services produced by all economic units. GDP at current prices illustrates the added value of goods and services calculated using the prevailing prices each year, while GDP at constant prices shows the added value of these goods and services which is calculated using the prevailing price in a particular year as the basis. . Kenya, is one of the countries that uses an open economic system where there is international trade and Kenya's o cial exchange rate is quite in uential on Kenya's economic conditions. A researcher named Irungu, Emily Njoki (Irungu, 2017) conducted a study entitled "Factors that in uence volatility in the Foreign Exchange Rate in Kenya" resulting in the nding that there is a positive and insigni cant relationship between loan interest rates and $o$ cial exchange rates, interest rates have a positive and signi cant e ect on the value of exchange rates, there is a negative and insigni cant correlation between in ation and the o cial exchange rate, in ation has a negative and signi cant e ect on the exchange rate, a positive and insigni cant correlation between trade ows and the o cial exchange rate, and trade ows have a signi cant positive and signi cant e ect on the exchange rate.

After experiencing an economic journey that almost took o and became an Asian tiger, in 1997 Indonesia experienced an economic depression. Rupiah plummeted, the US dollar exchange rate skyrocketed. In order to secure foreign exchange reserves, even though the Indonesian economy is not yet stable, the Indonesian government boldly began to implement a free oating exchange rate system and surrender the exchange rate fully to the market mechanism. The Indonesian economy is at stake there are in uential factors, especially aggregate factors that can be controlled, including in ation, the BI Rate and Net Exports through the establishment of policies which are expected to strengthen the Rupiah exchange rate against the USD. The USD exchange rate used here is the US Dollar Middle Exchange Rate against Rupiah at Bank Indonesia. Indonesia's economic conditions related to this research are shown in the following gure. According to Bank Indonesia 2013, inflation stability in (Pratama, I.,\& Tjun Tjun, 2018) The importance of controlling inflation is based on the consideration that high and 
unstable inflation has a negative impact on the socioeconomic conditions of society. Interest rates and exchange rates become unstable due to inflation, inflation also has an impact on interest rates and exchange rates. For more details, Table 1 can be illustrated in the graph as shown in Figure 1 below.

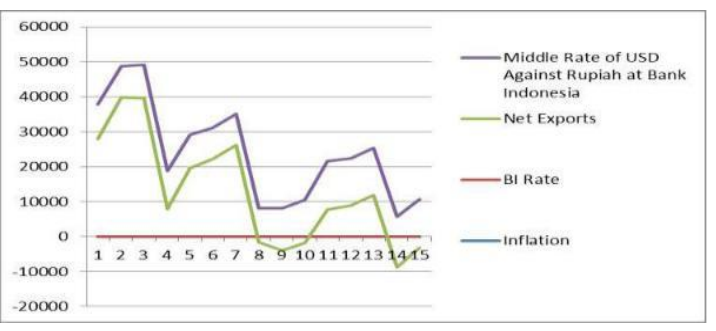

Figure 1. In ation, BI Rate, Net Exports and Middle Rate of USD Against Rupiah At Bank Indonesia 2005-2019 Curve.

Figure 1 describes the data In ation, BI Rate, Net Exports and the USD Middle Rate Against Rupiah at Bank Indonesia in 2005-2019. The results of this study are expected to be used to increase knowledge, as a scienti c reference for further research, and can be used as input for related parties.In ation is prices general increase in and continuously within a certain period (Harjunawati, S \& Hendarsih, 2020) Regarding in ation, the main objective of Bank Indonesia is the stability of the value of the rupiah against goods and services, which is re ected in the magnitude of the in ation rate. Ideal in ation rate is the in ation rate that supports economic growth, namely mild in ation which ranges from $1 \%$ $10 \%$ (Harjunawati, S \& Hendarsih, 2018) At this rate of in ation the business sector can freely move and develop its business so that it can absorb more labor, in the end the purchasing power of the community will increase as a result of increased income which in aggregate means an increase in Gross Domestic Income (GDP).

Based on the cause, in ation can be divided into demand in ation and cost in ation. In ation demand is in ation that arises because of an increase in aggregate demand, so it is often called a demand for pull of in ation. This in ation generally occurs in developed countries where there is an increase in people's purchasing power. Cost in ation is in ation that arises because of an increase in production costs and there is pressure from the supply side so it is often referred to as cost push in ation.

BI Rate is an interest rate policy that is determined and announced by Bank Indonesia to the public (Bank Indonesia, 2016) at each monthly meeting of the Board of Governors of Indone-sia.One tool to control monetary stability is to conduct Open Market Operations. In conducting open market operations, Bank Indonesia will direct the weighted average 1-month SBI interest rates from the auction of securities around the BI Rate. The BI Rate is expected to a ect in-terbank money market interest rates, deposit and credit interest rates in the long run to achieve Indonesian economic stability. In addition, the BI Rate is used as an in ation controller so that it remains within a predetermined target, for example by in uencing the amount of money circulating in the community through the regulation of the BI Rate. Directly or indirectly the BI Rate in uences business activities and subsequently will a ect the exchange rate because business people are one of the players in international trade. The exchange rate is one of the most important prices in an open economy, given its enormous influence on the current account balance and other macroeconomic variables. (Sukirno, 2016) the foreign exchange rate shows the price or the currency value of one country is expressed in terms of the currency of another country. exchange rate. Foreign currency can also be defined as the amount of domestic money required that is, the amount of rupiah needed to obtain one unit of currency foreign.

Net exports are the di erence between exports and imports. Exports are activities to move goods from customs areas as referred to in the Law on customs (Purba \& Magdalena, 2017). Import is the activity of entering goods into a customs area as referred to in the Law on customs (Ismanto, B. Rina, L \& Kristini, 2019)(Ismanto, B. Rina, L \& Kristini, 2019)(Ismanto, B. Rina, L \& Kristini, 2019). Exports are valued based on FOB value (free on ship). Imports are valued based on the Cost Insurance and Freight (CIF) value. The export value and import value are stated in US Dollars (USD).

Net exports with a positive value will add to foreign exchange reserves, while net exports have a negative value, will reduce foreign exchange reserves, and this means that the country has a balance of payments devicit. Thus, a country must increase sales to buyers in other countries which will increase net exports in that country.

In general is the value or price of a country's currency which is measured or expressed in the currency of another country. The definition of exchange rate (exchange rate) can also be interpreted as an agreement known as the exchange rate of the currency against the current or future payments between two currencies of different countries.

Exchange rate is the value of a currency against other currencies. The value of a particular currency at the time of purchase is not the same as the value of the currency at the time of sale. The terms of selling exchange rates, buying rates and middle rates are used by banks / money changers to bene $t$ from foreign exchange services. Middle rate is the middle value of the selling rate and the buying rate (Prasetyanwar, 2018).

\section{RESEARCH METHODS}

The method used in this research is quantitative descriptive research method. According to A.Muri Yusuf (A. Muri, 2017) this type of quantitative descriptive research is research that aims 
to systematically describe the facts and nature of certain populations, or describe phenomena that occur. In accordance with the research topic, namely In ation, the BI Rate, Net Exports and the Middle Rate of the USD against the Rupiah at Bank Indonesia in 2005-2019. This study discussed valid and reliable information data.

The data used in this study are secondary data from the o cial website of the Central Statistics Agency (BPS). The classic test used is the normality test, autocorrelation, and multi-collinearity test. Hypothesis tests used in this study are simple linear tests ( $\mathrm{t}$ test) and multiple linear tests (F test). Data processing was performed using SPSS.22. The research model is shown in Figure 2 below.

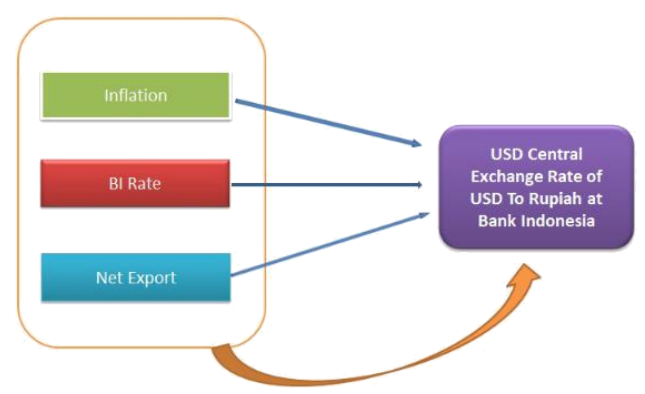

Figure 2. Research Model E ect In ation, BI Rate, Net Exports and USD Central Echange Rate To Rupiah In Bank Indonesia For 2005-2019.

From the model in Figure 2 the following hypotheses are presented:

- It is suspected that in ation has a partial e ect on the exchange rate of the USD against the Rupiah at Bank Indonesia.

- It is suspected that BI Rate has a partial e ect on the exchange rate of the USD against the Rupiah at Bank Indonesia.

- It is suspected that Net Export has a partial e ect on the exchange rate of the USD against the Rupiah at Bank Indonesia.

- Allegedly in ation, the BI Rate and Net Exports have a simultaneous e ect on the exchange rate of the USD against the Rupiah at Bank Indonesia.

\section{RESULT AND DISCUSSION}

\section{Classic Test}

Normality test shows that data is normally distributed. Sig. Value (2-tailed) of 0.200 is greater than 0.05 . This is con rmed by the results of the Zresid Histogram shaped like a bell and the points on the Normal P-P Plot of Regression Standardized Residual form a certain line from point 0 leading to the upper right.

The autocorrelation test produced a Durbin Watson value of 0.769. Durbin Watson's table for the number of samples 15 with the number of variables studied 4 with a $95 \%$ con dence level shows that DL is 0.81396 and DU is 1.75014 . Because the value of
Durbin Watson (0.769) is smaller than DL (0.81396), it can be concluded that there is a positive correlation in this study. Collinierity Test shows there is no relationship between independent variables. This conclusion is proven by the Tolerance Value for in ation of 0.250 ; BI Rate 0.187 ; Net exports of 0,569 and all three values are greater than 0.1. Other evidence is the result of the VIF value for In ation 3.998; BI Rate 5,342; and Net Export 1,757, and this value is smaller than 10 .

\section{Hypothesis Test}

\section{Simple Linear Regression Analysis (t Test)}

Simple Linear Regression Analysis (t test) in this study aims to nd out how much the relation-ship between independent variables and partially bound. $t$ table used is t table for the amount of data 15 and the number of variables $2(\mathrm{Df}=13)$ with a signi cance level of $5 \%$ or for testing the signi cance of 2 -sided $0.25 \%$ obtained $\mathrm{T}$ table value of 2.16037 . The following is a curve of acceptance and rejection of the partial correlation hypothesis in this study.

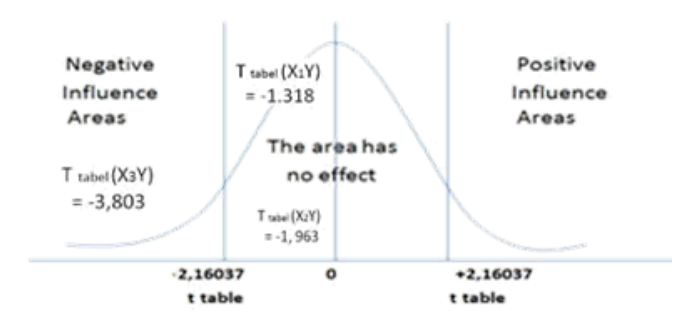

Figure 3. Regional Curve Acceptance and Rejection of the Partial Correlation Hypothesis Test

The above curve explains that the area of infuence is between the values of $-2,16037$ and $+2,16037$ or mathematically it is stated that 2,16037> T arithmetic > +2,16037.

The value of $t$ test for hypothesis 1 is $1.318>-2.16037$, the value of $t$ test for hypothesis 2 is $-1.318>-2.16037$ where the value of $t$ arithmetic is in the area of no e ect. This means that in ation or the BI Rate has no partial e ect on the USD Exchange Rate Against Rupiah at Bank Indonesia. Hypothesis 3 test yields $t-3.803<-2.16037$, is in the area of in uence, meaning that Net Exports partially in uences the USD Middle Rate Against Rupiah at Bank Indonesia.

\section{Multiple Linear Regression Test (F Test)}

Table F values at a signi cance of $5 \%$ with $\mathrm{df}$ $(3 ; 11)$ of 3,587 . The F test yields a Fcount of 4.670> 3,587 , meaning that in ation, the BI Rate, and Net Exports are simultaneously against the USD Middle Rate Against Rupiah at Bank Indonesia.

In addition, the signi cance value (sig.) In the table above 0.024 is smaller than 0.05 , reinforcing the 
conclusion that in ation, the BI rate, and net exports together in uence the Middle Rate of the US Dollar at Bank Indonesia.

Data processing using SPSS.22 produces Unstandardized Coe cients for a constant value of 12226.24; In ation is -166,022; The BI Rate is 196,115 and Net Export is $-0,101$ so it can be formulated in the regression equation as follows.

$\mathrm{Y}=12226,241-166,022 \cdot \mathrm{X} 1+196,115 \cdot \mathrm{X} 2-$ $0,101 . \mathrm{X} 3+\mathrm{e}$

\section{Note:}

$\mathrm{X} 1=\mathrm{In}$ ation $\mathrm{X} 2=\mathrm{BI}$ Rate

$\mathrm{X} 3=$ Net Export $=$ Export- Import

$\mathrm{Y}=$ The Middle Exchange Rate of USD Against Rupiah at Bank Indonesia

\section{Determination Analysis}

The Determination Analysis in this study yields a correlation $\mathrm{R}$ of 0.748 or $74.8 \%$ so that it can be interpreted that the independent variables In ation, the BI Rate, and Net Exports together have a strong in uence on the USD Middle Exchange Rate at Bank Indonesia.

In addition, the $\mathrm{R}$ square value of 0.56 means that the independent variables In ation, BI Rate, and Net Exports together account for $56 \%$ of the dependent variable in the USD Middle Rate at Bank Indonesia while the remaining $44 \%$ is in uenced by other variables not examined.

\section{CONCLUSION}

From the results of this study it can be concluded that in ation and the BI Rate in Indonesia do not have a partial e ect on the USD Middle Exchange Rate against the Rupiah at Bank Indonesia. Indonesia has managed to control in ation at a low in ation rate $(0-10 \%)$ a year, and is conducive to business development. The BI Rate has also been successfully controlled by Indonesia and does not a ect the Middle Rate of the USD against the Rupiah at Bank Indonesia. Net exports partially a ect the Middle Rate of the USD against the Rupiah at Bank Indonesia. It is from this net export that Indonesia's foreign exchange reserves are obtained and this greatly in uences the Middle Rate of the USD against the Rupiah at Bank Indonesia.

President Jokowi has tried to increase exports by engaging in cooperation with foreign countries, abolishing export taxes and simplifying the bureaucracy. What must continue to be done is to increase the added value of exported goods so that it is expected to further increase the value of Indonesia's exports going forward and be able to absorb more workers to reduce unemployment. The reduction in the value of imports must still be done by further tightening the selection of imported goods / services and making domestic products a king in their own country.

understanding GDP according to www.bps.go.id. GDP is basically the amount of added value produced by all business units in a particular country, or is the sum of the value of the final goods and services produced by all economic units. GDP at current prices illustrates the added value of goods and services calculated using the prevailing prices each year, while GDP at constant prices shows the added value of these goods and services which is calculated using the prevailing price in a particular year as the basis.

\section{REFERENCES}

A. Muri, Y. (2017). Metode Penelitian: Kuantitatif, Kualitatif Dan Penelitian Gabungan. Kencana (Vol. 16). Jakarta.

Bank Indonesia. (2016). BI Rate. Retrieved from https://www.bi.go.id/id/statistik/metadata/seki/ Documents/8_Suku_Bunga_Indo_DPM SEKI_2016 (Indonesia) new.pdf

Bps.go.id. (2021). Produk Domestik Bruto (Lapangan Usaha). Retrieved from https://www.bps.go.id/subject/11/produkdomestik-bruto--lapangan-usaha.html\#subjekViewTab1

Harjunawati, S \& Hendarsih, I. (2018). HUBUNGAN PRODUK DOMESTIK BRUTO DAN JUMLAH UANG BEREDAR TERHADAP INFLASI DI INDONESIA 2005-2017. MANAJERIAL. Penelitian Ilmu Manajemen, $1.1,121-130$.

Harjunawati, S \& Hendarsih, I. (2020). PENGARUH PENGANGGURAN DAN INFLASI TERHADAP PRODUK DOMESTIK BRUTO INDONESIA TAHUN 2009-2019. Pendidikan Dan Kewirausahaan, 7.2, 13-24. Retrieved from

https://doi.org/10.1017/CBO9781107415324.0 04

Irungu, E. N. (2017). Factors that in uence volatility in the Foreign Exchange Rate in Kenya. United States International University - Africa. Nairobi. Retrieved from http://erepo.usiu.ac.ke/bitstream/handle/11732/ 3326/EMILY NJOKI IRUNGU MBA 2017.pdf?isAllowed=y\&sequence $=1$

Ismanto, B. Rina, L \& Kristini, M. A. (2019). Pengaruh Kurs dan Impor Terhadap Pertumbuhan Ekonomi Indonesia Periode Tahun 2007-2017. Jurnal Universitas Kristen Satya Wacana, 2.1, 1-6. Retrieved from https://ejournal.uksw.edu/ecodunamika/article/ view/2279

Prasetyanwar, H. (2018). Peramalan Nilai Tukar IDR-USD Menggunakan Long Short Term Memory, 5.2.

Pratama, I.,\& Tjun Tjun, L. (2018). Pengaruh Suku 
Bunga Acuan dan Nilai Kurs Tengah Valuta Asing Terhadap Return Saham. Akuntansi Maranatha, 9.2, 180-185. Retrieved from file://C:/Users/Acer/Downloads/486-Article Text-613-1-10-20180119.pdf

Purba \& Magdalena, A. (2017). Pengaruh Nilai Tukar Terhadap Ekspor dan Dampaknya Terhadap Pertumbuhan Ekonomi Indonesia. DeReMa Jurnal Manajemen, 12.2, 285-295.

Sukirno, S. (2016). Makroekonomi: teori pengantar. (R. Pers, Ed.) (3rd ed.). Jakarta. 